\title{
COVID-19 panic, solidarity and equity-the Malta exemplary experience
}

\author{
Sarah Cuschieri ${ }^{1}$ (D)
}

Received: 22 April 2020 / Accepted: 7 May 2020 / Published online: 30 May 2020

(C) Springer-Verlag GmbH Germany, part of Springer Nature 2020

\begin{abstract}
Aim The coronavirus (SARS-CoV-2) pandemic is a global crisis, with more than 2 million of the world's population infected. Public health authorities across the world are working endlessly to contain the situation. The small nation of Malta has been applauded by the World Health Organization (WHO) Regional Director for Europe for the instituted escalated public health measures that have kept (up till the time of writing) the COVID-19 spread contained with low transmission rate. The aim of this overview is to give a comprehensive summary of the COVID-19 situation, measures, legislations and initiatives for containment, management and safeguarding the Maltese nation that were taken.

Subject and method A literature search was conducted using the Google search engine and Maltese online newspapers.

Results To date (22nd April 2020), the COVID-19 situation in Malta is a total confirmed cases of 444, of which 276 are active cases, 165 have recovered and there were three deaths. Various measures were taken early on, from travel bans to prohibition of more than three-person gatherings, backed up with penalties. Both public and private sectors are working together to ensure containment and provision of services to the population. Solidarity has spread across the country.

Conclusion A number of timely measures have been taken. However, it is down to the nation to continue to follow the restrictions and regulations instituted by the Superintendent of Public Health in conjunction with the health division and the government to overcome this pandemic together.
\end{abstract}

Keywords Pandemic $\cdot$ Coronavirus $\cdot$ Malta $\cdot$ Global health $\cdot$ Population health

\section{Introduction}

The novel virus SARS-CoV-2, also known as COVID-19 or coronavirus outbreak, was first reported in Wuhan, China. It has now spread across the world, causing global crisis and has been declared a pandemic (World Health Organization, WHO 2020a, b). As of 22nd April 2020, a total of 2,575,875 COVID-19 cases, 178,669 deaths and 704,142 recoveries were reported (Worldometer 2020). The USA (up till 22nd April) is the highest COVID-19-affected country, with a total of 819,175 cases ( 2475 cases per 1 million population), with Spain as the runner up, with a total of 208,389 cases (4457 cases per 1 million population) (Worldometer 2020). The small European country of Malta, on 22nd April, ranked as

Sarah Cuschieri

sarah.cuschieri@um.edu.mt

1 Department of Anatomy, Faculty of Medicine and Surgery, University of Malta, Msida, Malta the 99th country out of the world affected by COVID-19 and the 40th country out of 48 countries in Europe. It has, to date (22nd April), a total confirmed number of cases of 444 (1006 cases per 1 million population), out of which 276 are active cases, 165 have recovered and there were three deaths (Buttigieg 2020; Worldometer 2020). On 28th March 2020, the WHO Regional Director for Europe, Dr. Hans Henri P. Kluge, reported that "Malta's public health measures were an example to follow" (Grech Urpani 2020). This report aimed to give a comprehensive summary of the COVID-19 situation, measures, legislations and initiatives for containment, management and safeguarding the Maltese nation led by the Maltese Superintendent of Public Health in conjunction with the Ministry for Health and the Government of Malta.

\section{Malta and COVID-19}

The Maltese Islands (Malta and Gozo) situated in the middle of the Mediterranean Sea have a land area of $316 \mathrm{~km}^{2}$, with a 
total population of circa 492,000 and ranks the 7 th most densely populated country in the world. Preparations for the possibility of coronavirus spread started early, from January 2020, two months prior to the first actual COVID-19 case reported in Malta on the 7th March 2020 (Times of Malta 2020a; Cordina 2020). Nonetheless, panic shopping and fear among the population started with the first reported COVID19 case on the sister island of Sicily (Azzopardi and Hudson 2020; Caruana 2020a; Hudson 2020). A progressive increase in cases (age ranged between 1 month old to 92 years) ws observed, with various numbers of cases reported daily by the Superintendent of Public Health, in media briefs, as seen in Fig. 1. As in other countries, a sex disparity in the COVID-19 cases was observed, with $59.23 \%$ being male (up till 22nd April 2020) (Buttigieg 2020; Collier 2020). A call for further research to identify the cause of this COVID-19 sex disparity has been made. However, it has been postulated that underlying comorbidities and unhealthy lifestyle habits may be the reasons for this observation, where the male population tends to predominate (Wenham et al. 2020; Purdie 2020). In fact, this is the case in Malta, where the male population has been reported to be more metabolically at risk than the female population, as seen in Table 1 (Cuschieri et al. 2016a, b, 2017, 2018, 2019; Cuschieri 2020). Of concern is that a substantial proportion of the population (those with diabetes, obesity, cardiovascular disease) are at risk of acquiring complications if infected by COVID-19 (Fang et al. 2020; Simonnet et al. 2020).

Malta followed the WHO advice to undertake swabbing for COVID-19 to the maximum capacity of the human resources available (WHO 2020c). Initially, swabbing was done only on travellers arriving from abroad and who were symptomatic. However, on establishing local transmission, the swabbing covered anyone with any symptoms as well as random
Table 1 Prevalence of co-morbidities and smoking habits in the adult Maltese population [14-19]

\begin{tabular}{llr}
\hline Co-morbidity/lifestyle & Male* & Female* \\
\hline Type 2 diabetes & $13.56 \%$ & $6.98 \%$ \\
Impaired fasting glucose & $28.18 \%$ & $18.57 \%$ \\
Overweight & $39.39 \%$ & $31.81 \%$ \\
Obese & $36.89 \%$ & $31.25 \%$ \\
Hypertension & $35.04 \%$ & $25.09 \%$ \\
Global dyslipidaemia** & $23.77 \%$ & $14.62 \%$ \\
Smokers & $24.87 \%$ & $16.37 \%$ \\
\hline
\end{tabular}

*Patients aged 18-70 years representative data from a national health examination survey 2014-2016

**A combination of (i) population reported on statin medication and (ii) no medication but had a dyslipidaemic picture on blood testing

swabbing on healthcare workers, carers working in elderly homes and among inhabitants under lockdown within an immigrant centre. By 14th April, an average of 38.74 tests per 1000 population was reported, placing Malta the third highest testing country in the world after Luxembourg and Iceland (Caruana 2020b). Up to 22nd April, a total of 26,148 swabs had been taken (Buttigieg 2020).

\section{Preventive measures and legislations}

The Superintendent of Public Health, in conjunction with the Ministry for Health and the Government of Malta, instituted escalated preventive measures and legislations before the first COVID-19 case to pick up early-onset cases, contain the spread and prevent overwhelming the health services. In fact, to date (22nd April), only two COVID-19-positive patients are
Fig. 1 Time trend of reported COVID-19 cases in Malta during the 2 months of the outbreak

\section{COVID-19 CASES IN MALTA}

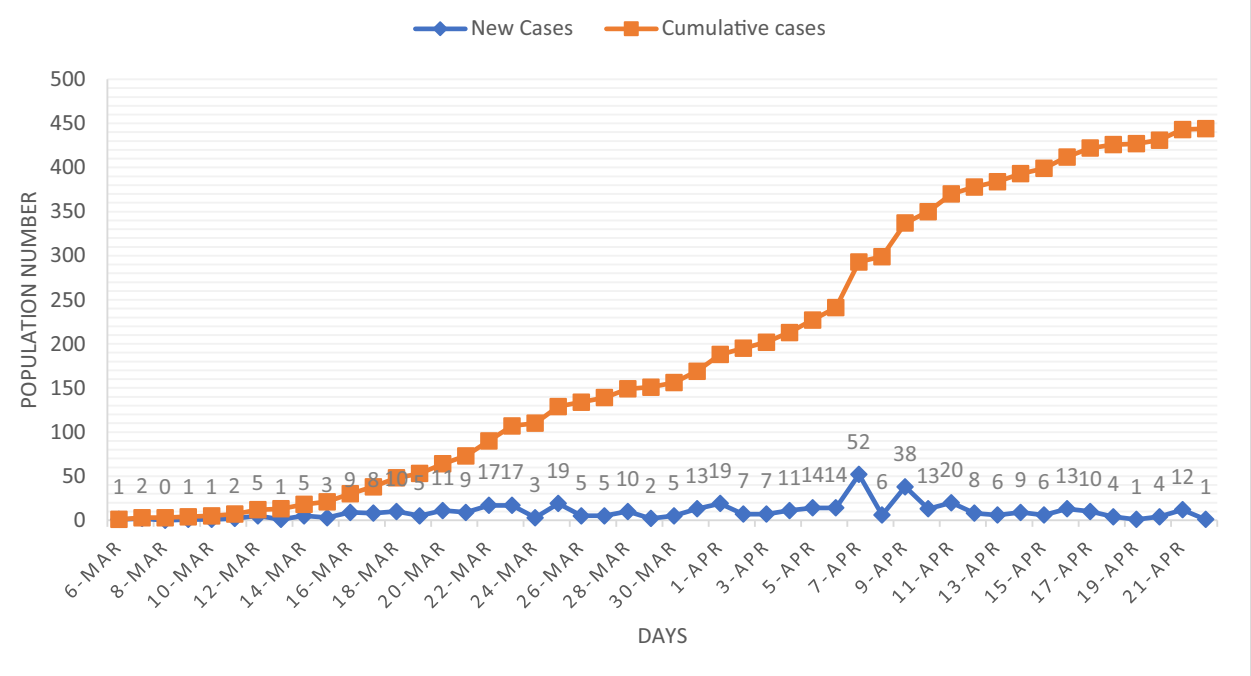




\section{4/02/2020 :}

Thermal screening at airport, cruise and catamaran terminals

\section{5/02/2020:}

Recommendation self-quarantine for travellers from Italy

\section{7/03/2020: \\ First COVID-19 case in Malta}

11/03/2020:

Travel ban to Germany, France, Spain \& Switzerland. Mandatory self-quarantine for all travellers with $€ 1 \mathrm{~K}$ fine if breached

\section{2//03/2020: political activities \\ $16 / 03 / 2020$ : \\ Mandatory quarantine fine increased to €3K}

Closure of all schools, care centers and religious, sports and

\section{2/03/2020: \\ Closure of non-essential retail and services. Banning of organised gatherings}

23/03/2020:

Protecting of the Vulnearble Group Act

02/04/2020:

Banning of more than 3 people gathered together

\section{8/04/2020: \\ First COVID-19 death}

\section{9/04/2020:}

Suspension of relative visitors to hospital patients

Fig. 2 Timeline of Malta COVID-19 events and preventive measures over a period of 7 weeks

receiving treatment within the intensive care unit, of which one required invasive ventilation.
A number of measures were instituted, as summarised in Fig. 2, which included travel bans and mandatory self- 
quarantine for anyone arriving in Malta for 15 days with a capital fine of $€ 1000$, which was then increased to $€ 3000$ for breaching (Costa and Azzopardi 2020; Superintendent of Public Health 2020a; Times of Malta 2020b; Diacono 2020b); closure of schools, universities, childcare centres, religious activities, sport or political activities, and non-essential retailer and services (Superintendent of Public Health 2020b; Diacono 2020a, c); as well as bans on group gatherings of more than 3 persons, with a fine of $€ 100$ per person if larger group gatherings were observed. A $€ 10,000$ fine was implemented for any COVID-19-positive individuals kept in the community but found in breach of their mandatory selfisolation during the spot checks carried out by health inspectors and the local police force (Commissioners for Justice Act 2020). Simultaneously, increases in ventilator machines, intensive care beds and hospital beds capacity were inclemently implemented within the state hospital of Mater Dei, as well as other public and private hospitals (Azzopardi 2020). Furthermore, plans for a prefabricated hospital to increase COVID-19 intensive treatment unit beds among other services are underway (Vassallo 2020). The COVID-19 swabbing sites increased from one within Mater Dei hospital and in an offsite premise to a total of four (three in Malta and one in Gozo). Attendance to these sites is through an appointment system after symptomatic individuals call the COVID-19 helpline (Caruana 2020b). Similar to other countries, a vulnerable person public health act legislation was set up to protect these groups (Superintendent of Public Health 2020c). Those falling under the vulnerable persons category were to be confined to their homes and only to leave the premises for essential requirements. A strong advocacy campaign was set up by the Superintendent of Public Health, backed up by the Directorate of Public Health, Ministry for Health and the Government of Malta for social distancing, staying at home, encouragement of employers to provide telework facilities to all employees, as well as to maintain a good personal hygiene measures, including regular washing of hands with soap etc. (Ministry for Health Malta 2020).

\section{Initiatives and solidarity}

\section{Helplines}

A number of governmental helplines were set up to aid in this crisis. There are dedicated helplines for coronavirus symptoms, for mental health, for general support, for the elderly, for assistance in quarantine and assistance for those stuck abroad. Organizations and non-governmental organisations also set up telephone and social media accounts for those feeling lonely, mental health advice and counselling (Malta Together 2020).

\section{Public health division}

The public health professionals including the Health Promotion and Disease Prevention Directorate and the Malta Association of Public Health Medicine (MAPHM 2020) have been working endlessly as part of the COVID-19 team in swabbing, contact tracing, advocating and providing reliable evidence to the population (MAPHM 2020; Ministry for Health Malta 2020; Calleja 2020).

\section{Assistance for food and basic needs}

A number of organisations set up food banks or food/basic aids services for those that have been economically challenged due to COVID-19 (Malta Together 2020).

\section{Financial aid packages}

The Government of Malta instituted three financial aid packages for the various companies, entities and families that experienced an economic disparity due to COVID-19 (KPMG 2020; PwC Malta 2020a, b).

\section{Other initiatives and solidarity}

A number of non-governmental organisations, local companies, professionals and individuals are giving a helping hand in this crisis, such as local manufacturing company changing their line of production to healthcare masks and qualified local chefs volunteering to cook for the healthcare professionals since the hospital's canteen had to undergo infrastructure changes due to COVID-19 (Aguis 2020; Caruana 2020c).

Solidarity being part of the Maltese soul could be observed, as the majority of the population joined together to lend a hand in this crisis while following the social distancing regulations. Such acts ranged from neighbourhoods setting up weekly roof and balcony gatherings to local artists conducting moving concerts across towns on Easter Sunday (Cassar 2020).

\section{The good, the bad and the evil}

The COVID-19 pandemic has challenged the daily living and normality of each population. Yet, it has brought about solidarity and appreciation to the front lines that, although have always been there working for the population, were previously 'invisible' to the public eye. Preventive measures initiated have reduced the air pollution and the frequency of asthma attacks in Malta (Watson 2020; Abela 2020). Furthermore, the restrictions applied in Malta appear to be working, since the spreading rate of COVID-19 is on the low side, with an $R_{0}$ of 1.5. However, it is down to the population to abide to the directives and restrictions set up by the authorities, with 
special attention to social distancing, to keep this low spread constant and try to reduce the $R_{0}$ value (Borg 2020). Nevertheless, this pandemic has brought fear, uncertainties, isolation and death. Countries' economies have hit rock bottom, which may be unsustainable over a long period of time. It is only through a global effort of containment, vaccine research and solidarity shall this pandemic be overcome.

\section{Conclusion}

The small country of Malta has shown a resilience across centuries and the COVID-19 pandemic is of no difference. The public health measures instituted have been praised by the World Health Organization (WHO) Regional Director for Europe and their effect could be seen in the low sheer numbers of daily COVID-19 cases. The support and work by various public and private entities are providing the required services and order during this period. Ultimately, it is down to the each and every individual to thoroughly follow the preventive measures and restrictions to keep the COVID-19 containment and substantial good outcomes in place.

\section{Compliance with ethical standards}

Conflict of interest This is an academic report and has not been financed nor delegated by the Superintendent of Public Health, the Ministry for Health or the Government of Malta.

Ethics approval Not applicable.

Informed consent Not applicable.

\section{References}

Abela K (2020) Drop in severe asthma attacks. Times of Malta. https:// timesofmalta.com/articles/view/drop-in-severe-asthma-attacks. 783635. Accessed 16 Apr 2020

Aguis M (2020) From school to kitchen: preparing food for healthcare workers. Newsbook. https://newsbook.com.mt/en/from-school-tokitchen-preparing-food-for-healthcare-workers/. Accessed 15 Apr 2020

Azzopardi K (2020) Coronavirus: 680 new beds inside and outside hospital to cater for Covid-19 patients. Malta Today. https://www. maltatoday.com.mt/news/national/101027/coronavirus_680_new beds_inside_and_outside_hospital_to_cater_for_covid19 patients\#.XpcAKKVMzaqQ. Accessed $1 \overline{5}$ Apr 2020

Azzopardi K, Hudson D (2020) Coronavirus fears prompt Maltese port workers to refuse to handle incoming cargo. Malta Today. https:// www.maltatoday.com.mt/news/national/100574/coronavirus fears_prompt_maltese_port_workers_to_refuse_to_handle incoming_cargo\#.XpbFIVMzaqR. Accessed 15 Apr 2020

Borg B (2020) COVID-19 is spreading at a slower rate in Malta than globally, models indicate. Times of Malta. https://timesofmalta. com/articles/view/covid-19-is-spreading-at-a-slower-rate-in-maltathan-globally-models.785567. Accessed 16 Apr 2020
Buttigieg S (2020) COVID-19 dashboard - Malta. Infogram. https:// infogram.com/1p1xpwwgj1w3v2imxjzwjvv152b63z02dvv? $\mathrm{f} \mathrm{b}$ c 1 i d = IwAR0Ht0zJadMBkRKPS8pLbo3iVHhJzlVizQRcftZcdcJFQ74SctWeNHMWHU. Accessed 15 Apr 2020

Calleja C (2020) Reliable information is the biggest weapon against virus. Times of Malta. https://timesofmalta.com/articles/view/reliableinformation-is-the-biggest-weapon-against-virus.783275. Accessed 15 Apr 2020

Caruana C (2020a) Panic buying at supermarkets over coronavirus concerns. Times of Malta. https://timesofmalta.com/articles/view/panicbuying-at-supermarkets-as-coronavirus-fears-mount. 773600 . Accessed 15 Apr 2020

Caruana C (2020b) Malta COVID-19 testing rate is among top three in the world, data suggests. Times of Malta. https:/timesofmalta.com/ articles/view/malta-covid-19-testing-rate-is-among-top-three-inthe-world-data.785597. Accessed 15 Apr 2020

Caruana C (2020c) Local clothes manufacturer sews 6,000 face masks. Times of Malta. https://timesofmalta.com/articles/view/6000masks-sewn-by-menswear-manufacturer.784169. Accessed 15 Apr 2020

Cassar D (2020) Two singers perform 11 concerts in one day. TVM News. https://www.tvm.com.mt/en/news/two-singers-perform-11concerts-in-one-day/. Accessed 15 Apr 2020

Collier I (2020) Coronavirus: Why does COVID-19 pose a greater threat to men than women? Sky News. https://news.sky.com/story/ coronavirus-why-does-covid-19-pose-a-greater-threat-to-men-thanwomen-11964453. Accessed 15 Apr 2020

Commissioners for Justice Act (2020) Service of notice relating to the enforcement of quarantine regulations. https://deputyprimeminister. gov.mt/en/health-promotion/covid-19/Documents/guidancedocuments/LN44_of_2020_-_Service_of_Notice_Relating_to Enforcement_of_Quarantine_Regulations.pdf. Accessed $1 \overline{5}$ Apr 2020

Cordina JP (2020) Further restrictions unnecessary unless coronavirus outbreak escalates - Fearne. Newsbook. https://newsbook.com.mt/ en/further-restrictions-unnecessary-unless-coronavirus-outbreakescalates-fearne/. Accessed 15 Apr 2020

Costa M, Azzopardi K (2020) Coronavirus: Mandatory quarantine introduced against $€ 1,000$ fine. Malta Today. https://www.maltatoday. com.mt/news/national/100934/coronavirus_robert_abela expected_to_announce_new_measures\#.Xpb86VM̄MaqS. Accessed 15 Apr 2020

Cuschieri S (2020) The diabetes epidemic in Malta. South East Eur J Public Health. https://doi.org/10.4119/seejph-3322

Cuschieri S, Vassallo J, Calleja N et al (2016a) Prevalence of obesity in Malta. Obes Sci Pract 2:466-470. https://doi.org/10.1002/osp4.77

Cuschieri S, Vassallo J, Calleja N et al (2016b) The diabesity health economic crisis - the size of the crisis in a European island state following a cross-sectional study. Arch Public Health 74:52. https://doi.org/10.1186/s13690-016-0164-6

Cuschieri S, Vassallo J, Calleja N, Pace N, Mamo J (2017) The effects of socioeconomic determinants on hypertension in a cardiometabolic at-risk European country. Int J Hypertens. https://doi.org/10.1155/ 2017/7107385

Cuschieri S, Vassallo J, Calleja N, Barbara C, Mamo J (2018) The interaction of dyslipidaemia with glycaemia in an adult population study. J Diabetes Metab Disord 17:315-323. https://doi.org/10.1007/ s40200-018-0377-z

Cuschieri S, Vassallo J, Calleja N, Mamo J (2019) Relationship of past, present, and passive smoking with sociodemographic, anthropometric, biochemical, and dysglycemic profiles. J Diabetes 11:87-89. https://doi.org/10.1111/1753-0407.12844

Diacono T (2020a) A full list of all the stores and services impacted by Malta's new restrictions. Lovin Malta. https://lovinmalta.com/news/ 
a-full-list-of-all-the-stores-and-services-impacted-by-maltas-newban/. Accessed 15 Apr 2020

Diacono T (2020b) Malta triples fine for violating mandatory quarantine rules to $€ 3,000$. Lovin Malta. https://lovinmalta.com/news/maltatriples-fine-for-breaching-mandatory-quarantine-rules-to-e3000/. Accessed 15 Apr 2020

Diacono T (2020c) BREAKING: Malta to close all bars, restaurants and gyms from tomorrow. Lovin Malta. https://lovinmalta.com/news/ news-breaking/breaking-malta-to-close-all-bars-restaurants-andgyms-from-tomorrow/. Accessed 15 Apr 2020

Fang L, Karakiulakis G, Roth M (2020) Are patients with hypertension and diabetes mellitus at increased risk for COVID-19 infection? Lancet Respir Med 8:e21. https://doi.org/10.1016/S2213-2600(20) 30116-8

Grech Urpani D (2020) 'An example to follow': WHO Europe Regional Director gives shout-out to Malta's COVID-19 measures. Lovin Malta. https://lovinmalta.com/news/news-international/anexample-to-follow-who-europe-regional-director-gives-shout-outto-maltas-covid-19-measures/. Accessed 15 Apr 2020

Hudson D (2020) Facebook panic on coronavirus sparks frenzied shopping sprees. Malta Today. https://www.maltatoday.com.mt/news/ national/100595/facebook_panic_on_coronavirus_sparks frenzied shopping sprees \#.XpbE $1 \overline{\mathrm{VM}}$ zaqR. Accessed $1 \overline{5}$ Apr 2020

KPMG (2020) Financial packages in response to COVID-19. KPMG Malta. https:/home.kpmg/mt/en/home/insights/2020/03/maltasfinancial-package-in-response-to-covid-19.html. Accessed 15 Apr 2020

Malta Association of Public Health Medicine (MAPHM) (2020) Coronavirus Malta - REAL public health advice on Covid19. Facebook. https://www.facebook.com/groups/covid19malta/? multi_permalinks=3024020160987935\&notif_id= $1585507824889978 \&$ notif_t=group_highlights\&ref=notif. Accessed 30 Mar 2020

Malta Together (2020) Malta Together | Malta | Services | COVID-19. https://www.maltatogether.com/. Accessed 15 Apr 2020

Ministry for Health Malta (2020) Novel coronavirus - English. https:// deputyprimeminister.gov.mt/en/health-promotion/Pages/Novelcoronavirus.aspx. Accessed 14 Apr 2020

Purdie A et al (2020) Sex, gender and COVID-19: Disaggregated data and health disparities. BMJ Global Health blog. https://blogs.bmj. $\mathrm{com} / \mathrm{bmjgh} / 2020 / 03 / 24 /$ sex-gender-and-covid-19-disaggregateddata-and-health-disparities/. Accessed 15 Apr 2020

PwC Malta (2020a) Financial aid package and measures introduced in light of COVID-19. https://www.pwc.com/mt/en/publications/taxlegal/covid-19-financial-aid-package.html. Accessed 15 Apr 2020

PwC Malta (2020b) Third financial aid package and measures introduced in light of COVID-19. https://www.pwc.com/mt/en/publications/ tax-legal/covid-19-third-financial-aid-package.html. Accessed 15 Apr 2020

Simonnet A, Chetboun M, Poissy J et al (2020) High prevalence of obesity in severe acute respiratory syndrome coronavirus- 2
(SARS-CoV-2) requiring invasive mechanical ventilation. Obesity. https://doi.org/10.1002/oby.22831

Superintendent of Public Health (2020a) Travel ban order, 2020. Public Health Act. https://deputyprimeminister.gov.mt/en/healthpromotion/Documents/LN42\%20of\%202020 Travel\%20Ban\% 20Order.pdf. Accessed 15 Apr 2020

Superintendent of Public Health (2020b) Closure of Schools Order, 2020 Public Health Act. https://deputyprimeminister.gov.mt/en/healthpromotion/covid-19/Documents/guidance-documents/LN41 Of 2020_-_Closure_Of_Schools_Order.pdf. Accessed 15 Apr 2020

Superintendent of Public Health (2020c) Protection of vulnerable persons order, 2020. Public Health Act. http://www.justiceservices.gov.mt/ DownloadDocument.aspx?app=lp\&itemid $=30044 \& 1=1$. Accessed 15 Apr 2020

Times of Malta (2020a) Malta's first coronavirus cases are girl and parents. Times of Malta. https://timesofmalta.com/articles/view/firstcoronavirus-case-reported-in-malta.776288. Accessed 15 Apr 2020

Times of Malta (2020b) Travel banned from another four countries, $€ 1$, 000 fine if quarantine ignored. Times of Malta. https://timesofmalta. com/articles/view/travel-banned-from-another-four-countries. 777314. Accessed 15 Apr 2020

Vassallo S (2020) Ministry for health issues call for tenders for prefabricated hospital that must be completed in 8 weeks. Lovin Malta. https://lovinmalta.com/news/ministry-for-health-issues-callfor-tenders-for-prefabricated-hospital-that-must-be-completed-in-8weeks/. Accessed 15 Apr 2020

Watson G (2020) Air pollution in Malta falls by up to 70 per cent in just one month. Times of Malta. https://timesofmalta.com/articles/view/ air-pollution-falls-by-up-to-70-per-cent-in-just-one-month.779603. Accessed 16 Apr 2020

Wenham C, Smith J, Morgan R (2020) COVID-19: the gendered impacts of the outbreak. Lancet 395:846-848

World Health Organization (WHO) (2020a) WHO Director-General's opening remarks at the media briefing on COVID-19 - 11 March 2020. https://www.who.int/dg/speeches/detail/who-directorgeneral-s-opening-remarks-at-the-media-briefing-on-covid-19\% 2D\%2D-11-march-2020. Accessed 15 Apr 2020

World Health Organization (WHO) (2020b) Novel coronavirus - China. https://www.who.int/csr/don/12-january-2020-novel-coronaviruschina/en/. Accessed 15 Apr 2020

World Health Organization (WHO) (2020c) WHO Director-General's opening remarks at the media briefing on COVID-19-16 March 2020. https://www.who.int/dg/speeches/detail/who-directorgeneral-s-opening-remarks-at-the-media-briefing-on-covid-19\% 2D\%2D-16-march-2020. Accessed 15 Apr 2020

Worldometer (2020) Coronavirus cases. Worldometer. https://www. worldometers.info/coronavirus/coronavirus-cases/\#daily-cases. Accessed 15 Apr 2020

Publisher's note Springer Nature remains neutral with regard to jurisdictional claims in published maps and institutional affiliations. 